DOI https://doi.org/10.30525/978-9934-26-005-6-15

\title{
МІСЦЕВЕ САМОВРЯДУВАННЯ В УКРАЇНІ ТА КРАЇНАХ СС: ПОРІВНЯЛЬНО-ПРАВОВИЙ АСПЕКТ
}

\author{
Толкачова I. A. \\ кандидат юридичних наук, \\ доцент кафедри конституиійного і адміністративного права \\ Національного авіаційного університету \\ Сокольвак В. Ю. \\ студентка юридичного факультету \\ Національного авіаиійного університету \\ м. Київ, Украӥна
}

Обмін досвідом в сфері місцевого самоврядування 3 країнами Свропейського Союзу є надзвичайно важливим для України. Це дозволяє нашій державі краще адаптуватися до методів державного управління європейських країн та сприяє швидшій євроінтеграції.

Згідно з Конституцією України місцеве самоврядування $є$ правом територіальної громади - жителів села чи добровільного об'єднання у сільську громаду жителів кількох сіл, селища та міста - самостійно вирішувати питання місцевого значення в межах Конституції і законів України (ст. 140) [1].

У країнах Європейського Союзу дане питання трактують як сукупність представницьких органів, які обираються місцевим населенням. Л. Штейн, Р. Гнейст, В. Безобразовий, А. Градовський та інші вважають, що органи місцевого самоврядування $є$ органами державного управління, статус яких регулюється державою. Згідно 3 теорією вільної громади, місцеве самоврядування - це особлива організація державної влади на місцях, яка заснована на виборних началах. Однак, на відміну від центрального державного управління, місцеве самоврядування здійснюється не урядовими чиновниками, а 
особами, які представляють інтереси місцевих спільнот [2, с. 201-202].

Місцеве самоврядування, за визначенням Європейської хартії місцевого самоврядування, $є$ правом і реальною здатністю органів місцевого самоуправління регламентувати значну частину публічних справ і управляти ними, діючи в межах закону, під свою відповідальність і в інтересах місцевого населення. Згідно 3 Хартією, це право здійснюється як виборними та виконавчими органами, так і безпосередньо територіальною громадою шляхом використання різних форм прямої демократії. Це означає, що розуміння даного феномену в Україні та країнах Європейського Союзу співпадає [3, с. 379].

Юридична природа місцевого самоврядування виявляється не тільки у відносинах його органів і держави, але й також (й іноді значно більше) у стосунках із громадянами, які нерідко звертаються по захист своїх прав і законних інтересів до судових інстанцій [3, с. 239].

Місцеве самоврядування являє собою відповідну систему, яка функціонує на конституційно-правових засадах. Дане поняття розглядається як сукупність органів та різноманітних організаційних форм, за допомогою яких відповідна територіальна громада або ii складові частини вирішують питання місцевого значення, здійснюють завдання та функції місцевого самоуправління [4, с. 384].

Згідно зі ст. 25 Закону України «Про місцеве самоврядування в Україні», сільські, селищні, міські ради правомочні розглядати i вирішувати питання, віднесені Конституцією України, цим та іншими законами до їх відання. Так, до повноважень органів місцевого управління в Україні належать: підготовка програм соціально-економічного та культурного розвитку сіл, селищ, міст, цільових програм 3 інших питань самоврядування; забезпечення збалансованого економічного та соціального розвитку відповідної території, ефективного використання природних, трудових i фінансових ресурсів; складання, схвалення та подання на розгляд відповідної ради прогнозу місцевого бюджету та інші повноваження, що 
забезпечують нормальне існування та функціонування даної територіальної громади [5].

Що ж до країн Європейського Союзу, їх органи місцевого самоврядування мають право здійснювати усі дії, які безпосередньо не заборонені законодавством та не знаходяться у віданні інших органів влади. До їх повноважень належать: право місцевих представницьких органів приймати місцевий бюджет, а також брати участь у формуванні державних фінансовоекономічних програм; право визначати діяльність місцевих поліцейських служб; право регулювати питання транспорту, дорожнього руху, місцевого будівництва, різних комунальних послуг; організація допомоги малозабезпеченим, інвалідам, утримання безкоштовних їдалень, домів для старих, підтримка муніципальних лікарень, шкіл, бібліотек, дитячих садків тощо [2, с. 215].

Доцільно зазначити, що як в Україні, так i країнах Європейського Союзу для кращого розуміння ролі органів місцевого самоврядування класифікують їх повноваження щодо певних сфер. Наприклад, повноваження у фінансово-економічній сфері, у галузях комунального обслуговування й охорони навколишнього середовища, будівництва, у сфері освіти, охорони здоров'я, культури, фізкультури і спорту, регулювання земельних відносин, соціальній тощо.

Для зміни старої неефективної системи місцевого самоврядування в Україні та підвищення рівня участі територіальних громад в управлінні державою, була розпочата реформа децентралізації, яка сьогодні перебуває у достатньо невизначеному стані, що не дає нам підстав очікувати іiі позитивних та якісних результатів у найближчому майбутньому.

Проте в країнах Європейського Союзу дана реформа вже завершена, що може бути для нас показовим прикладом. Звісно, децентралізація управління не гарантує швидке покращення ситуації та якості життя населення у громадах, але все ж таки даний процес суттєво збільшить можливості для кращого забезпечення територіальних спільнот необхідними послугами, що потрібні для їх нормального існування. 
У країнах Європейського Союзу місцеве самоврядування визначається як низка правил, процесів та норм поведінки, що стосуються способу реалізації владних повноважень, особливо щодо питань забезпечення їх відкритості, участі у громадському житті, підзвітності, ефективності та координованості дій. Основоположним аспектом реформ, що реалізуються інституціями Європейського Союзу з метою вдосконалення його системи врядування, є більш якісне залучення громадянського суспільства до процесів вироблення правил та політики на рівні Європейського Союзу (процедури консультацій та участі громадян у розробці державної політики) [6, с. 198].

Діяльність у цьому напрямі забезпечують певні засади і $з$ дотриманням таких вимог i принципів, як: відкритість, що передбачає активну комунікацію із громадськістю стосовно завдань і обов'язків різних органів влади та державних установ; участь - передбачає сприймання громадян та їх організацій не як пасивних об'єктів (або суб'єктів) політики й адміністративних рішень, а як безпосередніх, активних і зацікавлених сторін; ефективність - полягає в тому, що державна політика, законодавча й регуляторна системи повинні відповідати реальним суспільним потребам, мати чіткі цілі й прийматися 3 урахуванням оцінювання їх очікуваного впливу та попереднього досвіду та ін. [7, с. 106].

Отже, аналізуючи організацію роботи місцевого самоврядування в Україні та державах Свропейського Союзу, можна зробити висновок, що в Україні вже зроблені перші кроки до децентралізації. I тут, і там спостерігається тенденція щодо збільшення обсягу компетенції та повноважень місцевих органів управління, особливо у сферах освіти, медичного обслуговування, комунальних послуг тощо. Проте наша влада все одно повинна ще працювати над розвитком та покращенням даного напряму, щоб забезпечити територіальні громади всім необхідним. Потрібно надавати більше інформації, ефективно використовувати передані на місця кошти та реформувати місцеве самоврядування з врахуванням досвіду та законодавства країн Європейського Союзу й робити все можливе, щоб ці процеси не були уражені корупцією. 


\section{Література:}

1. Конституція України : прийнята на п'ятій сесії Верховної Ради України 28 червня 1996 р. Відомості Верховної Ради України. 1996. № 30. Ст. 141.

2. Конституційне право зарубіжних країн: навч. посіб. / За заг. ред. В. О. Ріяки. Київ, 2006. 544 с.

3. Панкевич О. 3. Державне право зарубіжних держав: підручник. Львів, 2018. 260 с.

4. Колісник В. П., Барабаш Ю.Г. Конституційне право України. Харків, 2008. 416 с.

5. Про місцеве самоврядування в Україні: Закон України від 21 травня 1997 р. Відомості Верховної Ради України. 1997. № 24. Ст. 170.

6. Колишко Р. А. Децентралізація публічної влади: історія та сучасні тенденції розвитку. Київ, 2003. 204 с.

7. Бусыгина И. Как менялась местная власть в Европе. Муницииальная власть. 2003. № 3. С. 106-109. 